\title{
Effect of Combination of Superdisintegrants on the Dissolution Rate: Meclizine Hydrochloride Fast Dissolving Tablets
}

\author{
Sateesh Kumar Vemula*, Biniam Paulos and Selamu Kebamo
}

\author{
College of Medical and Health Sciences, Wollega University, P.O Box: 395, Nekemte, Ethiopia
}

\begin{tabular}{|c|c|}
\hline \multirow{14}{*}{$\begin{array}{l}\text { Abstract } \\
\text { The aim of the present research is to develop the fast dissolving tablets and to study the } \\
\text { effect of combination of superdisintegrants on the dissolution rate by using meclizine } \\
\text { hydrochloride as a model drug. Development of oral fast dissolving tablets is mainly to } \\
\text { achieve the following objectives; they are to give fast onset of action and to overcome } \\
\text { difficulty in swallowing tablets and capsules that resulting in non-compliance. The prepared } \\
\text { tablets were characterized for hardness, weight variation, friability, wetting time, water } \\
\text { absorption ratio, and disintegration time. In vitro drug release studies were performed by } \\
\text { using USP XXIV Type II dissolution apparatus in } 0.1 \mathrm{~N} \mathrm{HCl} \text {. From in vitro dissolution studies, } \\
\text { the formulation F3 ( } 3 \% \text { crosscarmellose and } 3 \% \text { crosspovidone) showed rapid dissolution of } \\
\text { about } 99.34 \% \text { in } 15 \text { min, and disintegration time } 39 \text { sec when compared with others. The } \\
\left.\text { percent drug release in } 15 \text { min ( } Q_{15}\right) \text { and initial dissolution rate for formulation F } 3 \text { was } \\
99.34 \pm 0.56 \%, 6.54 \% / m i n \text {. These were very much higher compared to control tablets } \\
(36.48 \pm 0.82 \%, 2.43 \% / m i n) \text {. The dissolution efficiency was found to be increased by } 3.5 \text { fold } \\
\text { with F3 formulation compared to control tablet. From the stability studies, the similarity index } \\
\text { was found to be above } 50 \text { that indicates the stability of tablets. In conclusion, development } \\
\text { of meclizine hydrochloride fast dissolving tablets using combination of superdisintegrants is } \\
\text { showed improved results rather than the tablets with individual superdisintegrants. Further } \\
\text { the efficacy of the developed formulations has to be assessed by pharmacokinetic studies. }\end{array}$} & \\
\hline & History: \\
\hline & Received : 18-01-2015 \\
\hline & : 27-02-2015 \\
\hline & ted : 05-C \\
\hline & \\
\hline & \\
\hline & \\
\hline & S \\
\hline & te \\
\hline & Superdisintegrants \\
\hline & \\
\hline & \\
\hline & \\
\hline
\end{tabular}

\section{INTRODUCTION}

Development of oral solid dosage forms using insoluble drugs with the help of different methods is not only to enhance the solubility and dissolution rate of poor soluble drugs but also to improve the therapeutic efficacy (Chaitanya et al., 2014; Vemula and Katkum, 2014). Development of fast dissolving tablets can be achieved by various conventional methods like direct compression, wet granulation, spray drying, freeze drying, and sublimation (Seager, 1998; Hirani et al., 2009; Daravath et al., 2014). Among the different methods, use of superdisintegrants is one of the easiest and successful methods to enhance the dissolution rate. Formulation of fast dissolving tablets by integrating superdisintegrants is a user friendly, convenient and industry feasible method (Neduri et al., 2013). One of the advantages of incorporating the superdisintegrants is to provide fast disintegration due to combined effect of swelling and water absorption. Due to swelling of superdisintegrant, the wetted surface of the carrier increases that promote the wettability and dispersibility of the system, leads to enhance the disintegration and dissolution (Vemula et al., 2011).

Meclizine hydrochloride (MCZ) is a first-generation antihistamine of the piperazine class drug, used in the treatment of motion sickness. $\mathrm{MCZ}$ is a $\mathrm{H}_{1}$ receptor antagonist and practically insoluble in water (Vangala et al., 2014; Goyani et al., 2012). In the present study, fast dissolving tablets were prepared by direct compression method and studied the effect of various superdisintegrants and their concentration on the dissolution rate of $\mathrm{MCZ}$. Some of the recent research examples on MCZ dosage forms are Meclizine hydro chloride mouth dissolving tablets (Nimisha et al., 2012), Cyclodextrin-meclizine $\mathrm{HCl}$ Inclusion Complexes (George and Vasudevan, 2012), Metabolism and pharmacokinetics of meclizine suspension (Wang et al., 2012), Meclizine $\mathrm{HCl}$ orally disintegrating tablets (Mahrous et al., 2011), Meclazine-maltodextrin oro-dissolving tablets (Elnaggar et al., 2010).

In the previous research carried i.e., formulation and evaluation of meclizine hydrochloride fast dissolving tablets (Vemula et al., 2014), successfully developed the fast dissolving tablets using superdisintegrants like crosspovidone, crosscarmellose and sodium starch glycolate. In this study, formulation F6 tablets containing $8 \% \mathrm{w} / \mathrm{w}$ crosspovidone showed complete drug release within $20 \mathrm{~min}$ and rapid dissolution when compared to other formulations i.e., $98.12 \pm 0.34 \%$ in $20 \mathrm{~min}$. The current research was intended to develop MCZ fast dissolving tablets by direct compression method to study the effect of combination of superdisintegrants on the dissolution rate. In the present research, crosscarmellose and sodium starch glycolate were used in combination with crosspovidone to enhance the dissolution rate. 


\section{MATERIALS AND METHODS}

Materials

Meclizine hydrochloride is obtained as a gift sample from Symed labs Ltd, India. Crosspovidone, crosscarmelose and sodium starch glycolate were gift samples from Matrix laboratories, Hyderabad, India. All other chemicals used were of analytical grade.

\section{Preparation of Fast Dissolving Tablets (FDTs)}

Direct compression method was used to prepare the fast dissolving tablets (FDT's). MCZ, fixed ratio combination of superdisintegrants (Sodium starch glycolate: Crosspovidone and Crosscarmellose: Crosspovidone) other tabletting excipients were passed through a mesh 60 . The drug was mixed with proper portion of superdisintegrant with care to facilitate the proper mixing of drug and superdisintegrant. Then excipients other than lubricant and glidant were added and mixed in a poly bag for 5-10 min. The obtained blend was lubricated with magnesium stearate and talc for another $5 \mathrm{~min}$ and the resultant mixture was directly compressed into tablets with $6 \mathrm{~mm}$ round flat punches using rotary tabletting machine. In a similar manner, conventional control tablets were prepared without using superdisintegrants. The final weight of the tablet was adjusted to $100 \mathrm{mg}$ and the compositions of the tablets were given in Table 1 (Vemula and Veerareddy, 2011).

Table 1: Formulations of meclizine $\mathrm{HCl}$ fast dissolving tablets

\begin{tabular}{lccccccc}
\hline Ingredients (mg) & F1 & F2 & F3 & F4 & F5 & F6 & Control \\
\hline Meclizine HCl & 25 & 25 & 25 & 25 & 25 & 25 & 25 \\
Crosspovidone & 1 & 2 & 3 & 1 & 2 & 3 & - \\
Crosscarmellose & 1 & 2 & 3 & - & - & - & - \\
Sodium starch glycolate & - & - & - & 1 & 2 & 3 & - \\
Starch & - & - & - & - & - & - & 10 \\
Sodium lauryl sulphate & 1 & 1 & 1 & 1 & 1 & 1 & 1 \\
Mannitol & 25 & 25 & 25 & 25 & 25 & 25 & 25 \\
Avicel PH102 & 43 & 41 & 39 & 43 & 41 & 39 & 35 \\
Aspartame & 1 & 1 & 1 & 1 & 1 & 1 & 1 \\
Talc & 2 & 2 & 2 & 2 & 2 & 2 & 2 \\
Magnesium stearate & 1 & 1 & 1 & 1 & 1 & 1 & 1 \\
Total weight & 100 & 100 & 100 & 100 & 100 & 100 & 100 \\
\hline
\end{tabular}

\section{Evaluation of Physical Parameters}

After the preparation of tablets, all the formulations were evaluated for physical properties like weight variation, hardness and friability. For estimating weight variation, 20 tablets of each formulation were weighed using an Electronic weighing balance. The strength of tablet is expressed by measuring hardness and friability. The hardness of six tablets was measured using Monsanto tablet hardness tester. Friability was determined on ten tablets in a Roche friabilator for $4 \mathrm{~min}$ at $25 \mathrm{rpm}$ (Veerareddy and Vemula, 2012). For estimation of drug content, ten tablets were crushed, and the aliquot of powder equivalent to $50 \mathrm{mg}$ of drug was dissolved in suitable quantity of methanol/ $0.1 \mathrm{~N} \mathrm{HCl}$ solution. Solution was filtered and diluted and drug content determined by UV-Visible spectrophotometer at $232 \mathrm{~nm}$ (Vemula and Vangala, 2014).

\section{Determination of In Vitro Disintegration Time and Wetting Time}

In this study, the in vitro disintegration time of FDT's was determined by using the Gohel procedure. $10 \mathrm{ml}$ of water at room temperature was taken in a petridish of 10 $\mathrm{cm}$ in diameter. The tablet was then carefully placed in the centre of petridish and the time required for the tablet to completely disintegrate into fine particles was noted. Measurements were carried out in triplicates (Gohel et al., 2004). Wetting time was determined as described in the literature elsewhere. Briefly, two circular tissue papers were placed in a petridish of $10 \mathrm{~cm}$ diameter. Ten milliliter of water containing $0.5(\% \mathrm{w} / \mathrm{v})$ of phenol red was added to the petridish. The dye solution was used to identify the complete wetting of the tablet surface. A tablet was carefully placed on the surface of the paper in the petridish at room temperature. The time required for water to reach the upper surface of tablet and to completely wet them was noted as wetting time. Wetting time was recorded using stop watch and the measurements were carried out in triplicates (Bi et al., 1996).

\section{In Vitro Dissolution Study}

The in vitro dissolution study was carried out using USP XXIV Type II dissolution apparatus at a rotation speed of $50 \mathrm{rpm}$ and a temperature of $37 \pm 0.5^{\circ} \mathrm{C}$ for all the prepared FDT's. The drug release studies were carried out in $0.1 \mathrm{~N} \mathrm{HCl}$ buffer. An aliquot of $5 \mathrm{ml}$ was collected at predetermined time intervals and replaced with fresh dissolution medium. The samples were filtered through $0.45 \mu \mathrm{m}$ membrane filters and analyzed spectrophotometrically at $232 \mathrm{~nm}$ (Vaskula et al., 2012).

\section{Calculation of Dissolution Parameters}

Cumulative percent drug release was plotted as a function of time and percent drug release in $15 \mathrm{~min}\left(Q_{15}\right)$ was calculated. Initial dissolution rate (IDR) was calculated as percentage dissolved of drug over the first 15 min per minute. Dissolution efficiency (DE) was calculated from the area under the dissolution curve at time $t$ (measured using the trapezoidal rule) and expressed as a percentage of the area of the rectangle described by $100 \%$ dissolution in the $15 \mathrm{~min}$. Relative dissolution rate (RDR) is the ratio between amount of drug dissolved from best formulation and that dissolved from the marketed tablets at 15 min (Vemula and Veerareddy, 2011).

\section{Stability Studies}

According to $\mathrm{ICH}$ guidelines, stability studies were carried on $\mathrm{F} 3$ formulation to judge the drug and formulation stability. Best formulation (F3) was sealed in aluminum packaging coated inside with polyethylene, and three replicates were kept in the humidity chamber maintained at $40 \pm 2{ }^{\circ} \mathrm{C}$ and $75 \pm 5 \% \mathrm{RH}$ for six months (Chaudhary et al., 2011). Samples were collected after six 


\section{Sateesh Kumar Vemula et al.,}

months of storage and analyzed for the drug content and in vitro dissolution rate and they were subjected to statistical analysis using paired $t$-test to test the significance of difference at 0.05 level of significance (LS). Then the similarity index was calculated between dissolution rates of optimized tablets before and after storage to prove the stability of the dosage form (Vemula and Veerareddy, 2013; Vemula and Bontha, 2013).

\section{RESULTS AND DISCUSSION}

\section{Evaluation of Physical Parameters}

The evaluated different physical parameters of MCZ fast dissolving tablets were given in Table 2. In weight variation test, the pharmacopoeial limit for the tablets of not more than $7.5 \%$ of the average weight. The hardness of the tablets was found to be in the range of 2.8 to 3.1 $\mathrm{kg} / \mathrm{cm}^{2}$. Another measure of tablets strength is friability.
Sci. Technol. Arts Res. J., Jan-March 2015, 4(1): 124-128

The percentage friability for all formulations was below $1 \%$ i.e., 0.24 to 0.36 , indicating that the friability is within the prescribed limits. The tablets were found to contain $98.64 \pm 0.59$ to $99.78 \pm 0.32 \%$ of the labeled amount indicating uniformity of drug content.

\section{Determination of In Vitro Disintegration Time and Wetting Time}

The disintegration time of all formulations was found in the range of $39.52 \pm 0.38$ to $58.21 \pm 0.42$ sec. The wetting time of formulated tablets was found in the range of $59.24 \pm 0.45$ to $79.68 \pm 0.27$. From the results, the formulation $\mathrm{F} 3$ containing $3 \%$ crosscarmellose and $3 \%$ crosspovidone showed the fastest disintegration (39 sec) and less wetting time (59 $\mathrm{sec}$ ) as compared to other formulations (Table 2).

Table 2: Evaluation of meclizine $\mathrm{HCl}$ fast dissolving tablets

\begin{tabular}{|c|c|c|c|c|c|c|}
\hline Formulation & $\begin{array}{l}\text { Weight variation* } \\
\text { (mg) }\end{array}$ & $\begin{array}{l}\text { Hardness } \\
\left(\mathrm{kg} / \mathrm{cm}^{2}\right)\end{array}$ & Friability (\%) & $\begin{array}{c}\text { Drug content } \\
\text { uniformity } \\
(\%)\end{array}$ & $\begin{array}{c}\text { In vitro } \\
\text { Disintegration } \\
\text { Time }^{\#}(\mathrm{sec})\end{array}$ & $\begin{array}{c}\text { Wetting } \\
\text { Time }^{\#} \text { (sec) }\end{array}$ \\
\hline F1 & $99.28 \pm 0.34$ & $2.8 \pm 0.12$ & 0.32 & $98.64 \pm 0.59$ & $50.29 \pm 0.76$ & $71.32 \pm 0.21$ \\
\hline $\mathrm{F} 2$ & $101.32 \pm 0.23$ & $3.1 \pm 0.38$ & 0.36 & $99.42 \pm 0.74$ & $43.92 \pm 0.54$ & $64.86 \pm 0.38$ \\
\hline F3 & $100.28 \pm 0.49$ & $3.0 \pm 0.42$ & 0.24 & $99.78 \pm 0.32$ & $39.52 \pm 0.38$ & $59.24 \pm 0.45$ \\
\hline F4 & $100.49 \pm 0.64$ & $2.9 \pm 0.18$ & 0.36 & $99.34 \pm 0.78$ & $58.21 \pm 0.42$ & $79.68 \pm 0.27$ \\
\hline F5 & $98.97 \pm 0.72$ & $3.0 \pm 0.24$ & 0.24 & $98.27 \pm 0.24$ & $44.16 \pm 0.23$ & $75.18 \pm 0.49$ \\
\hline F6 & $100.02 \pm 0.48$ & $2.8 \pm 0.34$ & 0.28 & $99.78 \pm 0.56$ & $41.48 \pm 0.51$ & $61.82 \pm 0.74$ \\
\hline Control & $101.24 \pm 0.45$ & $3.0 \pm 0.14$ & 0.32 & $99.16 \pm 0.82$ & $298.92 \pm 0.68$ & $246.38 \pm 0.42$ \\
\hline
\end{tabular}

\section{In vitro Dissolution Study}

Figure 1 demonstrated the MCZ release patterns from F1-F6 fast dissolving tablets. From the in vitro dissolution studies, tablets containing combination of crosscarmellose and crosspovidone showed fast dissolution rate than others. Among all the formulations, F3 tablets showed complete drug release within $15 \mathrm{~min}$ and rapid dissolution when compared to other formulations i.e., $99.34 \pm 0.56 \%$ in $15 \mathrm{~min}$. Where as in the similar conditions, the control tablets of same dose was showed $36.48 \pm 0.82 \%$ drug release in $15 \mathrm{~min}$ (Figure 2). Similar type of results showed in a study i.e., piroxicam fast disintegrating tablets (Vemula et al., 2010). The possible reasons and mechanisms for increased dissolution rates are formation of porous structure on the surface of tablet due to sublimation and the presence of superdisintegrants enhance the water permeation (wicking action) in to the tablet leads to fasten the wetting action, disintegration time and finally causes the fast dissolution rate (Vemula et al., 2010).

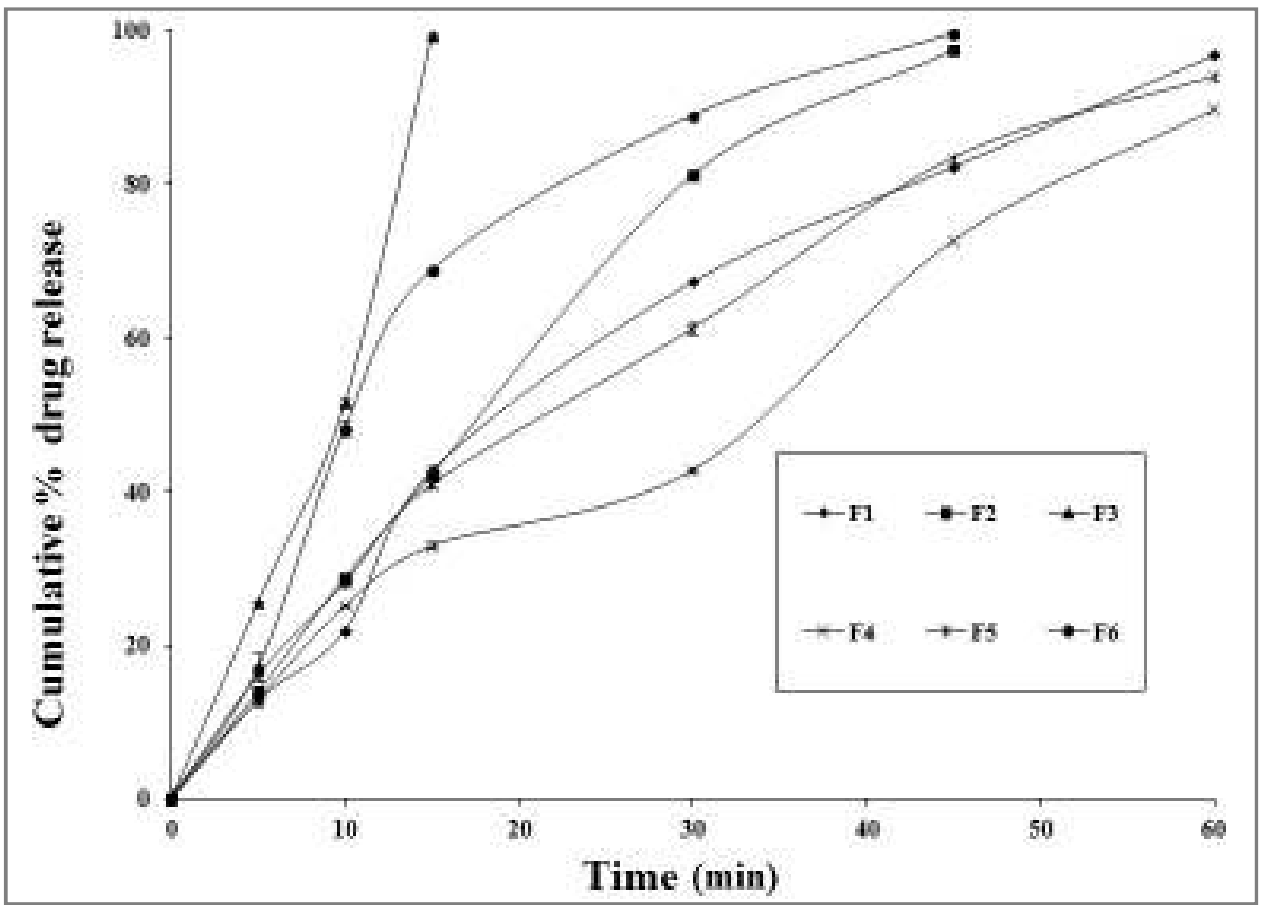

Figure 1: Release profile of MCZ from fast dissolving tablets $(n=3)$ 


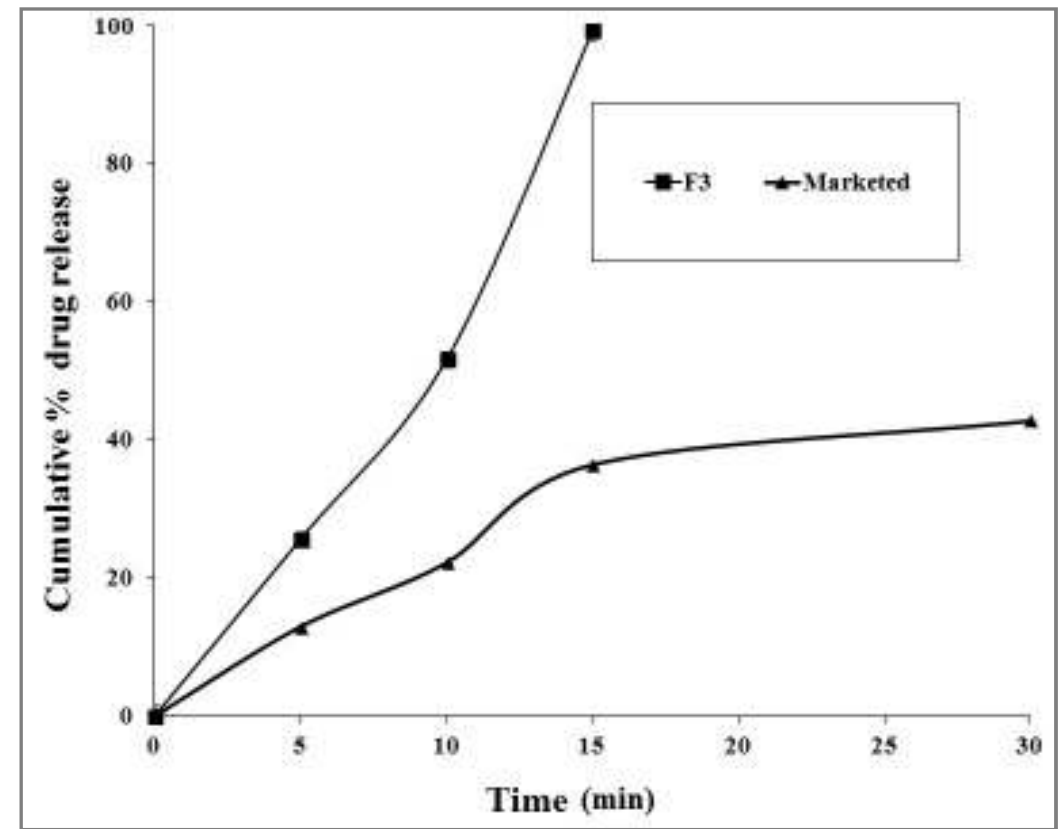

Figure 2: Comparison of Release profile of MCZ from fast dissolving and control tablets $(n=3)$

\section{Calculation for Dissolution Parameters}

The percent drug release in $15 \mathrm{~min}\left(\mathrm{Q}_{15}\right)$ and initial dissolution rate (IDR) for formulation $F_{3}$ was $99.34 \pm 0.56$ $\%, 6.54 \%$ per min. These were very much higher compared to marketed tablets $(36.48 \pm 0.82 \%, 2.43 \%$ per $\mathrm{min})$. The improvement in the dissolution characteristics of a drug described in terms of dissolution efficiency (DE) and relative dissolution rate (RDR). The RDR was found to be 2.69. The DE was found to be 42.35 and it is increased by 3.0 fold with F6 FDTs compared to control tablets i.e., 17.82 (Table 3). Similar type of improvement in IDR, DE, RDR was reported in the study of Vemula et al i.e., flurbiprofen fast disintegrating tablets (Vemula and Veerareddy, 2011).

Table 3: Dissolution parameters of meclizine $\mathrm{HCl} \mathrm{F3}$ and control tablets

\begin{tabular}{ccccc}
\hline Formulation & $\left(\mathbf{Q}_{15}\right)$ & IDR (\%/min) & DE & RDR \\
\hline F3 tablet & $99.34 \pm 0.56$ & 6.54 & 42.35 & \multirow{2}{*}{2.69} \\
Control tablet & $36.48 \pm 0.82$ & 2.43 & 17.82 & \\
\hline \multicolumn{5}{c}{ All results represent Avg \pm SD, $\mathrm{n}=3$}
\end{tabular}

\section{Stability Studies}

After storage of six months, F3 tablets were subjected to drug assay and in vitro dissolution studies (Table 4) and from the statistical analysis there was no significant difference between before and after storage $(P<0.05)$.
The similarity index value between dissolution profiles of optimized formulation before and after storage was found to be 82.13 , which is more than 50 indicates similarity between the dissolution profile before and after storage (Vemula et al., 2014a; Vemula et al., 2014b).

Table 4: Stability studies of meclizine $\mathrm{HCl} \mathrm{F3}$ fast dissolving tablets

\begin{tabular}{ccccc}
\hline Time (min) & Before storage & $\begin{array}{c}\text { After } \mathbf{6} \text { months } \\
\text { storage }\end{array}$ & t-test at $\mathbf{0 . 0 5}$ LS & Similarity Factor (F2) \\
\hline 0 & $0.00 \pm 0.00$ & $0.00 \pm 0.00$ & & \\
5 & $25.67 \pm 0.28$ & $22.34 \pm 0.78$ & Not Significant & 82.13 \\
10 & $51.71 \pm 0.56$ & $49.67 \pm 0.84$ & & \\
15 & $99.34 \pm 0.56$ & $98.12 \pm 0.24$ & & - \\
\hline \% Assay & $99.62 \pm 0.51$ & $98.27 \pm 0.46$ & Not Significant & \\
\hline \multicolumn{5}{c}{ *All results represent Avg \pm SD, $n=3$}
\end{tabular}

\section{CONCLUSIONS}

An effort was made to develop the fast dissolving tablets of meclizine hydrochloride using combination of superdisintegrants to enhance the dissolution rate. Meclizine hydrochloride fast dissolving tablets were formulated using direct compression method and evaluated for different parameters, which were found in the acceptable range. From the dissolution studies of prepared tablets, F3 fast dissolving tablets containing $3 \%$ crosscarmellose and $3 \%$ crosspovidone showed rapid disintegration time and fast dissolution rate. The percent drug release in $15 \mathrm{~min}\left(Q_{15}\right)$ and initial dissolution rate
(IDR) for formulation $\mathrm{F}_{3}$ was $99.34 \pm 0.56 \%, 6.54 \%$ per $\mathrm{min}$. These were very much higher compared to marketed tablets $(36.48 \pm 0.82 \%, 2.43 \%$ per min). The DE was found to be increased by 3.0 fold with F3 FDTs compared to control. The similarity index value between dissolution profiles of optimized formulation before and after storage was found to be 82.13 , which is more than 50 indicates similarity between the dissolution profile before and after storage In conclusion, development of fast dissolving tablets using combination of superdisintegrants by direct compression method is a suitable and feasible method to improve the dissolution rate of meclizine hydrochloride. 
Sateesh Kumar Vemula et al.,

\section{Acknowledgements}

The authors acknowledge the Symed labs Ltd, India and Matrix laboratories India for gift samples. The authors also thank to Chaitanya College of Pharmacy Education and Research, Hanamkonda, India for providing facilities.

\section{Conflict of Interest}

Authors declared no conflict of interest.

\section{REFERENCES}

Bi, Y., Sunanda, H., Yonezawa, Y., Danjo, K., Otuska, A., lida, K. (1996). Preparation and evaluation of a compressed tablet rapidly disintegrating in the oral cavity. Chemical and Pharmaceutical Bulletin 44(11): 2121-2127.

Chaitanya, P., Jyothi, P., Devadasu, V.R., Venisetty, R.K., Vemula, S.K. (2014). Ezetimibe solid dispersions: formulation, development and in vitro evaluation. American Journal of Advanced Drug Delivery 2(1): 90103.

Chaudhary, A., Tiwari, N., Jain, V. (2011). Microporous bilayer osmotic tablet for colon-specific delivery. Europian Journal of Pharmaceutics and Biopharmaceutics 78: 134140.

Daravath, B., Tadikonda, R.R., Vemula, S.K. (2014). Formulation and pharmacokinetics of gelucire solid dispersions of flurbiprofen. Drug Development and Industrial Pharmacy. doi: 10.3109/03639045.2014. 940963.

Elnaggar, Y.S., El-Massik, M.A., Abdallah, O.Y., Ebian, A.E. (2010). Maltodextrin: a novel excipient used in sugarbased orally disintegrating tablets and phase transition process. AAPS PharmSciTech 11(2): 645-651.

George, S., Vasudevan, D. (2012). Studies on the preparation, characterization, and solubility of $2-\mathrm{HP}-\beta$ cyclodextrin-meclizine $\mathrm{HCl}$ inclusion complexes. Journal of Young Pharmacist 4(4): 220-227.

Gohel, M., Patel, M., Amin, A., Agrawal, R., Dave, R., Bariya N. (2004). Formulation design and optimization of mouth dissolve tablets of nimesulide using vacuum drying technique. AAPS PharmSciTech 5: Article 36.

Goyani, M., Shah, P., Vyas, B., Shah, D. (2012). Formulation and evaluation of orodispersible tablets of meclizine hydrochloride. International Research Journal of Pharmacy 3: 196-199.

Hirani, J.J., Rathod, D.A., Vadalia, K.R. (2009). Orally disintegrating tablets: a review. Tropical Journal of Pharmaceutical Research 8(2): 161-172.

Mahrous, G.M., Shazly, G.A., Ibrahim, M.A. (2011). Formulation and evaluation of meclizine $\mathrm{HCl}$ orally disintegrating tablets. Bulletin of Pharmaceutical Sciences 34 (2): 141-148.

Neduri, K., Bontha, V.K., Vemula, S.K. (2013). Different techniques to enhance the dissolution rate of lovastatin: formulation and evaluation. Asian Journal of Pharmaceutical and Clinical Research 1: 56-60.

Nimisha, Pal, P., Srivastava, D. (2012). Formulation and evaluation of meclizine hydro chloride mouth dissolving tablets: An attempt to enhance patient compliance. Indian Journal of Pharmaceutical Science 4(6): 307-311.

Seager, H. (1998). Drug-deliver products and the zydis fastdissolving dosage form. Journal of Pharmacy and Pharmacology 50: 375-382.
Sci. Technol. Arts Res. J., Jan-March 2015, 4(1): 124-128

Vangala, M., Veerareddy, P.R., Devadasu, V.R., Vemula, S.K. (2014). Meclizine hydro chloride fast dissolving tablets by sublimation method: formulation and evaluation. American Journal of Advanced Drug Delivery 2(2): 133-144.

Vaskula S., Vemula, S.K., Bontha, V.K., Garrepally, P. (2012). Liquisolid compacts: An approach to enhance the dissolution rate of nimesulide. Journal of Applied Pharmaceutical Science 02(05): 115-121.

Veerareddy, P.R., Vemula, S.K. (2012). Formulation, evaluation and pharmacokinetics of colon targeted pulsatile system of flurboprofen. Journal of Drug Targeting 20(8): 703-714.

Vemula, S.K., Paulos, B., Kebamo, S. (2014). Formulation and evaluation of meclizine hydrochloride fast dissolving tablets. Proceedings of the National Symposium on "Science, Technology and Innovation for National Development" Wollega University, Nekemte, Ethiopia. ISBN: 978-99944-889-2-6: 140-148.

Vemula, S.K., Bontha, V.K., Garrepally, P., Chilukala, S., Madavapeddi, A.K. (2011). Development and characterization of fast disintegrating tablets of terbinafine hydrochloride. Journal of Pharmacy Research 4(7): 22732275.

Vemula, S.K., Garrepally, P., Bontha, V.K. (2010). Development and characterization of fast disintegrating tablets of Piroxicam. Inventi Impact: Pharm Tech 1(3): 169-173.

Vemula, S.K., Katkum, R. (2014). Development and physical characterization of meclizine hydrochloride solid dispersions by using polyethylene glycol 8000 . Science, Technology and Arts Research Journal 3(1): 48-52.

Vemula, S.K., Vangala, M. (2014). Formulation development and characterization of meclizine hydrochloride sublimated fast dissolving tablets. International Scholarly Research Notices 2014: Article ID 281376, 8 pages. doi:10.1155/2014/281376.

Vemula, S.K., Veerareddy, P.R. (2011). Fast disintegrating tablets of flurbiprofen: formulation and characterization. Latin American Journal of Pharmacy 3: 1135-1141.

Vemula, S.K., Veerareddy, P.R. (2013). Formulation, evaluation and pharmacokinetics of ketorolac tromethamine time-dependent colon targeted drug delivery system. Expert Opinion Drug Delivery 10: 33-45.

Vemula, S.K., Bontha, V.K. (2013). Colon targeted gaur gm compression coated tablets of flurbiprofen: formulation, development and pharmacokinetics. BioMed Research International 2013: Article ID 287919, 8 pages. doi:10.1155/2013/287919.

Vemula, S.K., Veerareddy, P.R., Devadasu, V.R. (2014a). Pharmacokinetics of ketorolac tromethamine compression-coated tablets for colon delivery. Drug Delivery and Translational Research 4: 310-319.

Vemula, S.K., Veerareddy, P.R., Devadasu, V.R. (2014b). Pharmacokinetics of colon-specific $\mathrm{pH}$ and timedependent flurbiprofen tablets. European Journal of Drug Metabolism and Pharmacokinetics. doi: 10.1007/s13318014-0210-0 (Article in Press).

Wang, Z., Lee, B., Pearce, D., Qian, S., Wang, Y., Zhang, Q., Chow, M.S. (2012). Meclizine metabolism and pharmacokinetics: formulation on its absorption. Journal of Clinical Pharmacolology 52(9): 1343-1349. 